\title{
TINJAUAN HUKUM ADMINISTRASI NEGARA TERHADAP PEMBAYARAN PAJAK
}

\author{
Nufaris Elisa, $\mathrm{SH}, \mathrm{MH}$ \\ Universitas Amir Hamzah \\ nufariselisa5@gmail.com
}

\begin{abstract}
Abstrak
Satu bidang yang menjadi sasaran kebijakan hukum pemerintah adalah pajak. Pajak merupakan sumber pendapatan negara selain sumber pendapatan lainnya. Hal tersebut dapat dilihat pada setiap Rancangan Undang-Undang tentang Anggaran Pendapatan dan Belanja Negara (RUUAPBN) yang disusun oleh pemerintah yang menempatkan pajak sebagai pendapatan utama. Demikian pentingnya pajak bagi negara, pemungutannya didasarkan pada Pasal 23 A Undang-Undang Dasar Negara Republik Indonesia tahun 1945 yang mengatur bahwa "Pajak dan pungutan lain yang bersifat memaksa untuk keperluan negara diatur dengan undang-undang. Bumi dan bangunan memberikan keuntungan dan kedudukan sosial ekonomi yang baik bagi orang atau badan yang mempunyai hak atasnya atau memperoleh 2 manfaat dari padanya, oleh karena itu wajar apabila mereka diwajibkan memberikan sebagian dari manfaat atau kenikmatan yang diperolehnya kepada negara melalui pajak, yaitu pajak bumi dan bangunan. Pengaturan pajak bumi dan bangunan, terdapat dalam Undang-Undang Nomor 12 Tahun 1994 Tentang Perubahan Atas Undang- Undang Nomor 12 Tahun 1985 Tentang Pajak Bumi dan Bangunan.
\end{abstract}

Kata kunci : Hukum Administrasi Negara, Pembayaran Pajak

\section{PENDAHULUAN}

Pengetahuan tentang sanksi dalam perpajakan menjadi penting karena pembuat undang-undang memilih menerapkan self assessment system dalam rangka pelaksanaan pemungutan pajak. Berdasarkan sistem ini, wajib pajak diberikan kepercayaan untuk menghitung, menyetor, dan melaporkan pajaknya sendiri. 
Untuk dapat menjalankannya dengan baik, maka setiap wajib pajak memerlukan pengetahuan. pajak, baik dari segi peraturan maupun teknis administrasinya. Agar pelaksanaannya dapat tertib dan sesuai dengan target yang diharapkan, pemerintah telah menyiapkan rambu-rambu yang diatur dalam undang-undang perpajakan yang berlaku. Dari sudut pandang yuridis, pajak memang mengandung unsur pemaksaan. Artinya, jika kewajiban perpajakan tidak dilaksanakan, maka ada konsekuensi hukum yang bisa terjadi. Konsekuensi hukum tersebut adalah pengenaan sanksi-sanksi perpajakan. Pada hakikatnya, pengenaan sanksi perpajakan diberlakukan untuk menciptakan kepatuhan wajib pajak dalam melaksanakan kewajiban perpajakannya. Itulah sebabnya, penting bagi wajib pajak memahami sanksi-sanksi perpajakan sehingga mengetahui konsekuensi hukum dari apa yang dilakukan ataupun tidak dilakukan. Meskipun secara normatif pemerintah telah mengeluarkan ketentuan hukum bagi wajib pajak yang tidak memenuhi kewajibannya atau terlambat memenuhi kewajibannya, namun pada kenyataannya pemerintah belum secara optimal melakukan penegakkan hukum terhadap wajib pajak yang tidak memenuhi kewajibannya berupa pengenaan sanksi kepada wajib pajak tersebut. Salah satu faktor yang menjadi kendala bagi pemerintah dalam memberikan sanksi di bidang hukum pajak adalah belum optimalnya sosialisasi kepada masyarakat sebagai wajib pajak mengenai pentingnya membayar pajak dan sanksi yang akan diterima apabila wajib pajak melalaikan kewajibannya.

\section{KAJIAN PUSTAKA}

Soeparman Soemahamidjaja mengemukakan bahwa pajak adalah iuran wajib, berupa uang atau barang, yang dipungut oleh penguasa berdasarkan norma-norma hukum, guna menutupi biaya produksi barang-barang dan jasa-jasa kolektif dalam mencapai kesejahteraan umum . Pajak diartikan sebagai iuran wajib, ini artinya pembayaran pajak merupakan kewajiban. Penegasan lebih lanjut dinyatakan bahwa pembayaran pajak dilaksanakan atas dasar undang-undang, konsekensinya 
apabila kewajiban ini tidak dilaksanakan sebagaimana mestinya, undang-undang akan mengatur pelaksanaan lainnya sebagai imbalan tidak terpenuhinya yang telah ditetapkan. Penyelenggaraan keamanan, kesejahteraan, pembangunan, dan lainlain merupakan manifestasi pemberian kontraprestasi bagi pembayaran pajak selaku anggota masyarakat. Pajak berada dalam pengawasan pejabat pajak sebagai pihak yang mewakili negara dan tidak ada tegen prestasi secara langsung kepada wajib pajak. Sifat yang dimiliki oleh pajak adalah bersifat memaksa dan terjelma dari aspek penagihan dengan ancaman hukuman berupa sanksi administrasi maupun sanksi pidana.

Sanksi administrasi sebagai upaya untuk memaksa wajib pajak agar menaati ketentuan-ketentuan yang terkait dengan pelaksanaan kewajiban dibidang perpajakan. Sekalipun sifatnya memaksa, pejabat pajak yang bertugas mengelolah pajak pusat dan daerah tidak boleh sewenang-wenang menerapkannya, agar tidak terjadi perbuatan melanggar hukum pajak. Sanksi ini bukan sebagai penghukum namun mengingatkan wajib Pajak agar teliti dan berhati-hati. Sanksi merupakan perlakuan tertentu yang sifatnya tidak mengenakkan atau menimbulkan penderitaan, yang diberikan kepada pihak pelaku perilaku menyimpang. Sanksi administrasi adalah pengenaan bunga, denda atau kenaikan atas ketidakpatuhan wajib pajak dalam menjalankan kewajiban administrasi perpajakan. Sanksi administrasi tidak tertuju pada fisik wajib pajak melainkan hanya berupa penambahan jumlah pajak yang terutang karena ada sanksi administrasi yang harus dibayar oleh wajib pajak.

\section{DISCUSSION}

\section{Penerapan Sanksi Administratif bagi Wajib Pajak yang Terutang Pajak Bumi dan Bangunan}

Berdasarkan Undang-Undang Nomor 28 Tahun 2009 Tentang Pajak Daerah dan Retribusi Daerah, pengalihan pemungutan pajak bumi dan bangunan perkotaan keseluruh pemerintahan kabupaten/kota dimulai paling lambat 1 Januari 2014. 
Dengan pengalihan ini, penerimaan pajak bumi dan bangunan perkotaan akan sepenuhnya masuk ke pemerintahan kabupaten/kota sehingga diharapkan mampu meningkatkan jumlah pendapatan asli daerah (PAD). Pengelolaan pajak bumi dan bangunan dilaksanakan oleh Dispenda melalui unit pelaksana teknis dinas pajak bumi dan bangunan (UPTD PBB). Adapun kewenangan yang dialihkan dari pemerintah pusat ke kabupaten/kota antara lain proses pendataan, penilaian, penetapan pengadministrasian, penagihan, dan pelayanan pajak. Dalam hal penagihan pajak bumi dan bangunan, apabila wajib pajak tidak memenuhi kewajibannya maka akan dikenakan sanksi administrasi. Sanksi administrasi dalam pajak bumi dan bangunan sebagaimana yang telah dijelaskan dalam tinjauan pustaka adalah sebagai berikut:

a. Tidak menyampaikan surat pemberitahuan objek pajak (SPOP), Walaupun telah ditegur secara tertulis dikenai sanksi berupa denda $25 \%$ dari pokok.

b. Berdasarkan hasil pemeriksaan atau keterangan lain ternyata jumlah pajak terutang lebih besar dari jumlah pajak yang dihitung berdasarkan SPOP, maka selisih pajak terutang tersebut ditambah atau dikenakan sanksi administrasi berupa denda $25 \%$ dari selisih pajak terutang.

c. Membayar atau kurang bayar. Pajak yang terutang pada saat jatuh tempo pembayaran, dikenakan sanksi administrasi berupa denda $2 \%$ sebulan yag dihitung dari saat jatuh tempo sampai dengan hari pembayaran untuk jangka waktu paling lama 24 bulan.

\section{Faktor-Faktor yang Mempengaruhi Penerapan Sanksi Administratif bagi} Wajib Pajak yang Terutang Pajak Bumi dan Bangunan

Faktor-faktor yang mempengaruhi penerapan sanksi administrasi adalah unsurunsur penting yang akan sangat membantu dalam pelaksanaan penagihan guna mencapai hasil yang diinginkan.

1. Faktor Kesadaran Wajib Pajak Seorang wajib pajak harus menyadari bahwa dengan membayar pajak merupakan bentuk partisipasi dalam menunjang pembangunan daerah. Dengan begitu wajib pajak akan membayar pajaknya karena merasa tidak dirugikan dari pemungutan pajak 
yang dilakukan. Apabila kesadaran wajib pajak tinggi untuk membayar pajak maka kepatuhan membayar pajak pun akan tinggi dan akan menambah pendapatan daerah. Dan apabila wajib pajak telah memenuhi dan memahami kewajibannya sebagai wajib pajak maka wajib pajak akan membayar pajaknya.

2. Faktor Ekonomi Walaupun wajib pajak memiliki sebidang tanah atau beberapa bidang tanah, hal tersebut tidak dapat menjamin bahwa wajib pajak dapat memenuhi kewajibannya untuk membayar pajak. Beberapa wajib pajak adalah orang yang memiliki penghasilan rendah atau dalam golongan ekonomi rendah sehingga tidak mampu membayar pajak untuk tanah yang dimilikinya. Adakalanya wajib pajak yang tidak mampu membayar pajak bumi dan bangunan perkotaan tersebut adalah wajib pajak yang mendapatkan tanah dari hibah atau warisan orangtua mereka. Kebanyakan dari mereka berpikir dari pada membayar denda lebih baik mencukupi kebutuhan hidup yang semakin mahal.

3. Faktor Pemahaman Tentang Perpajakan Pemahaman wajib pajak terhadap peraturan perpajakan adalah cara wajib pajak dalam memahami peraturan perpajakan yang telah ada. Wajib pajak yang tidak memahami peraturan perpajakan secara jelas cenderung akan menjadi wajib pajak yang tidak taat. Jelas bahwa semakin paham wajib pajak terhadap peraturan perpajakan, maka semakin paham pula wajib pajak terhadap sanksi yang akan diterima bila melalaikan kewajiban perpajakan mereka. Dimana wajib pajak yang benar-benar paham, mereka akan tau sanksi adminstrasi dan sanksi pidana sehubungan dengan SPT dan NPWP.

\section{KESIMPULAN}

\section{Kesimpulan}

1. Penerapan sanksi administrasi bagi wajib pajak yang terutang pajak bumi dan bangunan telah diterapkan dengan benar oleh Dinas Pendapatan Daerah sesuai dengan peraturan perundang- undangan. 
2. Faktor-faktor yang mempengaruhi penerapan sanksi administrasi bagi wajib pajak yang terutang pajak bumi dan bangunan perkotaan terbagi menjadi dua, yaitu:

a. Faktor pendukung: kemudahan dalam pembayaran dan adanya kesadaran wajib pajak.

b. Faktor penghambat: Kurangnya kesadaran wajib pajak, faktor ekonomi, dan kurangnya pemahaman tentang perpajakan.

\section{Saran}

1. Dalam menjalankan tugasnya, diharapkan para petugas pemungut pajak bumi dan bangunan dapat memberikan pelayanan dan informasi yang terbaik bagi wajib pajak yang berhubungan dengan pembayaran dan sanksi administrasi bagi wajib pajak agar wajib pajak dapat mengetahui proses dan kewajibannya.

2. Dalam menjalankan kewajibannya, diharapkan wajib pajak mempunyai kesadaran membayar pajak tepat waktu karena itu akan bermanfaat juga bagi wajib pajak. Dengan pembayaran yang tepat waktu, maka pendapatan daerah yang berasal dari pajak juga akan tepat dan pembangunan didaerah pun akan lancar.

\section{REFERENCES}

Aji Suryo dan Valentina Sri Sumardiyanti. 2006.

Perpajakan Indonesia. Yogyakarta: AMP YKPN. Bohari. 2010.

Pengantar Hukum Pajak. Jakarta: PT Rajagrafindo Persada. Eny Supriapti dan Setu Setyawan. 2004.

Perpajakan. Malang: Bayu Media. Erly Suandy. 2002.

Hukum Pajak. Jakarta: Salemba Empat. Harry Hartono dan Untung Supardi. 2010.

Membedah Pengelolaan Administrasi PBB \& BPHTB. Jakarta: Mitra wacana media. Imam Soebechi. 2012. 
Judicial Review Perda Pajak dan Retribusi Daerah. Jakarta: Sinar Grafika. Mardiasmo. 2004.

Perpajakan. Yogyakarta: Andi Offset. Muhammad Djafar Saidi. 2014.

Pembaruan Hukum Pajak. Jakarta: Rajawali Pers. Munawir. 1998.

Perpajakan. Yogyakarta: Liberty. Ridwan HR. 2014.

Hukum Administrasi Negara Edisi Revisi. Jakarta: Rajagrafindo Persada. Richard Burton dan Wirawan Ilyas. 2001.

Pengantar Ilmu Hukum Pajak. Bandung: Eresco. Soerjono Soekanto. FaktorFaktor Yang Mempengaruhi Penegakan Hukum. Jakarta: PT. Raja Grafindo Persada. 2008 